\title{
Ortaokul Öğrencilerinin Okul Tükenmişliği, Öğrenme Sürecinde Yardım İstemeleri ve Akademik Başarıları Arasındaki İlişkinin İncelenmesi*
}

\section{Examining the Relationship Between School Burnout, Help-Seeking During Learning Process and Academic Achievement of Secondary School Students}

\author{
Abdulaziz ÇELIK ${ }^{(i D}$ 1, Dr. Öğr. Üyesi Ata PESEN ${ }^{(D 2}$
}

\begin{abstract}
$\ddot{\mathbf{O} z}$
$\mathrm{Bu}$ araştırma 6. 7. ve 8. sınıf öğrencilerinin okul tükenmişliği ve öğrenme sürecinde yardım istemeleri ile genel akademik başarı düzeyleri arasındaki ilişkinin belirlenmesi amacıyla yapılmıştır. Araştırma ilişkisel tarama modelinde desenlenmiştir. Araştırma Siirt il merkezinde okuyan 990 ortaokul öğrencisi ile gerçekleştirilmiştir. Verilerin analizinde Pearson korelasyon katsayısı analizleri uygulanmıştır. Araştırmada öğrencilerin okul tükenmişliği ve tüm alt boyutları ile akademik başarı arasında negatif yönde ve düşük düzeyde anlamlı bir ilişki olduğu belirlenmiştir. Ayrıca öğrencilerin öğrenme sürecinde yardım isteme ve bütün alt boyutları ile akademik başarı arasında anlamlı bir ilişki olduğu belirlenmiştir. Son olarak öğrencilerin okul tükenmişliği ölçeğinin tüm alt boyutları ile öğrenme sürecinde yardım isteme ölçeğinin tüm alt boyutları arasında anlamlı bir ilişki olduğu tespit edilmiş̧ir.
\end{abstract}

Anahtar Kelimeler: Okul tükenmişliği, öğrenme süreci, yardım isteme, akademik başarı

Makale Türü: Araştırma

\begin{abstract}
This research was carried out to determine the relationship between 6th, 7th and 8th grade students' school burnout, help-seeking during learning process and their general academic achievement levels. This research was designed in correlational survey model. The population of the study was consisted of secondary school 990 students in Siirt city center. SPSS 21 package program was used to analyze the data. In the analysis of the data, Pearson correlation coefficient was used. Results demonstrated a significant negative correlation between all sub-dimensions of school burnout and academic achievement of students. In addition, a significant relationship between all the sub-dimensions of help-seeking during learning process and their academic achievement was found. Finally, a significant relationship between all sub-dimensions of school burnout scale and all sub-dimensions of help-seeking scale during learning process was demonstrated.
\end{abstract}

Keywords: School burnout, learning process, help-seeking, academic achievement

Paper Type: Research

\footnotetext{
${ }^{*}$ Bu çalışmanın Abdulaziz ÇELİK'in Siirt Üniversitesi Sosyal Bilimler Enstitüsünde Dr. Öğr. Üyesi Ata PESEN danışmanlığında tamamladığı aynı isimli yüksek lisans tezinden üretilmiştir.

${ }^{1} \mathrm{MEB}, 75$. Y11 İlkokulu, abdlzzclk56@gmail.com.

${ }^{2}$ Siirt Üniversitesi, Eğitim Fakültesi, atapesen @ siirt.edu.tr.
}

Atıf için (to cite): Çelik, A. ve Pesen A. (2020). Ortaokul öğrencilerinin okul tükenmişliği, öğrenme sürecinde yardım istemeleri ve akademik başarıları arasındaki ilişkinin incelenmesi. Afyon Kocatepe Üniversitesi Sosyal Bilimler Dergisi, 22(2), 351-362. 


\section{Giriş}

Öğrencilerin öğrenme sürecinde akademik başarılarını; seçtikleri eylem planları, gösterdikleri çaba, karşılaştıkları engeller, başarısızlıklar konusunda sürdürdükleri kararlılık, zorluklara karşı gösterdikleri direnç, çevrelerinden yardım isteme becerileri, kendilerine has düşünce kalıpları, çevrenin beklentilerine cevap vermede yaşadıkları stres ve depresyon düzeyi etkilemektedir. Öğrencilerin okul hayatına psikolojik perspektiften bakıldığında, bir çalışan olmamalarına karşın okuldaki görev ve sorumluluklarının sürekli devam etmesi nedeniyle öğrencilik hayatı bir meslek olarak kabul edilmektedir (Kutsal ve Bilge, 2012). Okul tükenmişliği kavramı mesleki tükenmişlik kavramının bir türevi olarak son yıllarda ortaya çıkmış ve dünyanın birçok yerinde araştırmacıların üzerinde çalıştığı bir problem alanı haline gelmiştir. Bu yönü ile okul tükenmişliği oldukça yeni bir kavram olup, öğrencilerin okul yaşamından ve yoğun akademik taleplerden dolayı bitkinlik yaşamalarını, okula ve ödevlere karşı ilgisiz tutumlarını, yetersizlik duygularını içinde barındırır (Salmelo-Aro ve Upadyaya, 2014).

Öğrencilerin okulda yapmış oldukları çalışmalar ile ilgili olarak bireysel kapasitelerinin yetersiz olması, öğrencinin kendisinden beklediği ile ebeveynleri, akranları, öğretmenleri ve akrabalarından meydana gelen çevresinin kendisinden bekledikleri arasındaki uyumsuzluk ve olumsuzluklar okul tükenmişliğini tetikler. Öğrencide oluşan stres ile bağlantılı olan okul tükenmişliğinin öğrencide meydana getireceği tahribat öğrencinin okulda veya derslerinde elde edeceği başarı ile ters orantılıdır. Başarmaya olan inancını yitiren öğrencinin düşük öğrenme güdüsü; azalmış öz yetkinlik ve düşük akademik öz alg1 ile benzerlik göstermektedir (Kiuru, Aunolo, Nurmi, Leskinen ve Salmelo-Aro, 2008; Özgen, 2016).

Öğrencinin yaşadığı tükenmişlik okula devam etmeme, okulu aksatma, okula düzensiz gelme, derslere olan ilginin düşüklüğ̈̈, derslerde sıkılma, okulu bırakma veya okul terki oranında artışlar gibi bazı sonuçlar doğurmaktadır. (Aypay ve Eryılmaz, 2011) Öğrenme sürecinde, okunan derslerin fazlalığ 1 , derslerden kaynaklı olarak meydana gelen stres veya öğrenciyi baskı altına alacak olan diğer ruhsal unsurlar, öğrencide duygusal tükenme, duyarsızlaşma eğilimi ve düşük başarı hissine neden olabilir (Yang ve Farn, 2005; McCarthy, Pretty ve Catano, 1990). Ulaş1lması istenen amaçlara ulaşmayı kolaylaştıran önemli bir öz düzenleme stratejisi olarak kabul edilen öğrenme sürecinde yardım isteme becerisi ise akademik açıdan öğrencilerin üstesinden gelemeyecekleri kadar zor işlerle karşılaştıklarında bu zorluğun üstesinden gelmek için doğru kişiden yardım alması veya doğru yöntemi kullanmasıdır. Driscoll (2012)'a göre başarının veya başarısızlığın iç sebepleri kişinin içindeki yetenek, çaba ve ruh hali etmenleridir. Dış sebepler ise görevin zorluğu, öğretmenin tutumu, diğer insanlardan yardım ve benzeri gibi öğrenenin dışındaki faktörlerdir. Bu bakımdan öğrencilerin belirtilen tükenmişlikleri yaşamamaları adına öğrenme sürecinde yardım isteme becerilerini geliştirmek ve okulu sevdirmek önemlidir.

Yardım isteme; öğrencilerin öğrenme sürecine ve öğrenme aşamalarına aktif olarak katılmalarını sağlayarak akademik zorluklar ile başa çıkmaları için öğrencileri destekleyen genel bir problem çözme stratejisi (Nelson Lee Gall ve Resnick, 1998) olmasının yanında, öğrencinin içerisinde bulunduğu sosyal ortamı öğrenmeyi arttıracak biçimde düzenleme yolu olarak da ifade edilmektedir (Schunk, 2009; Akt. Koç, 2014). Bireyin yardıma muhtaç olduğunu fark etmesiyle yardım isteme süreci başlamakta, bu süreç bazı becerilerin (duyuşsal, toplumsal, bilişsel, vb) ortaya konması ile devam etmekte, daha sonra elde edilen yardımın işe koşulması ile süreç sona ermektedir. Birden fazla değişkenin sürece tesir etmesinden kaynaklı olarak bu süreç karmaşıktır (Koç, 2014). Dolayısıyla öğrenciler birbirleri ile olan bağlantılarında başarılarını daha üst seviyelere çıkarmak ve bu tür seviyelerde kalıcı olmak için birbirlerine yardım etmeli ve öğrenme amacıyla giriştikleri çabalara destek vermeli, birbirlerinin cesaretlerini arttırmalı, motivasyonlarını yükseltmeli, birbirlerine yol göstermeli ve karşılıklı olarak birbirlerini ödüllendirmelidirler (Saban, 2005).

Okul tükenmişliği ile ilgili yapılan literatür araştırmasında ölçek geliştirme-uyarlama çalışmaları (Aypay, 2011; Çapri, Gündüz ve Gökçakan, 2011) Türkiye'de üniversite 
öğrencilerinin okul tükenmişliğini incelemeye yönelik çalışmalar (Akbaşl1, Arastaman, Gün \& Turabik, 2019; Çam, Deniz ve Kurnaz, 2014; Gündüz, Çapri ve Gökçakan, 2012; Küçüksüleymanoğlu ve Eğilmez, 2013; Ören ve Türkoğlu,2006; Özgen, 2016; Seçer, 2015; Seçer, 2015a; Tansel, 2015) ve Lise öğrencilerinin okul tükenmişliğini inceleyen çalışmalar (Atik, Özer ve Karadağ, 2018; Avara, 2015; Aypay ve Ery1lmaz, 2011;Aypay ve Eryılmaz, 2011a; Aypay ve Sever, 2015; Çakır, 2015; Eker, 2007; Koçak ve Secer, 2018; Kutsal, 2009; Kutsal ve Bilge, 2012; Seçer ve Gençdoğan, 2012) olduğu görülmektedir.

Ortaokul öğrencilerinin okul tükenmişliğini inceleyen araştırmalar incelendiğinde (Altuntaş ve Sezer, 2017; Baş, 2012; Çakmak ve Şahin, 2017; Özbakır, 2015; Özdemir, 2015; Özdemir ve Özdemir, 2015; Öztan, 2014; Saka, 2016; Şahan ve Duy, 2017) dışında ilköğretim ikinci kademe öğrencilerine yönelik pek fazla çalışmaya rastlanmamıştır. Literatür incelendiğinde tükenmişlik ile alakalı araştırmaların daha çok lise düzeyi öğrencilerine yönelik olduğu, son zamanlarda üniversite öğrencilerine yönelik çalışmalarda artış olduğu görülürken ortaokul öğrencilerine yönelik çalışmaların sayısının kısıtlı olması dikkat çekmiştir.

Öğrenme sürecinde yardım isteme ile ilgili Türkiye'de yapılan araştırmalar incelendiğinde ise bu konu ile ilgili çok sınırlı çalışmalar olduğu görülmüştür (Güvenç ve Koç, 2016; Koç, 2014; Koç, 2015; Körükçü ve Uslu, 2018). Yurt dışında ise öğrenme sürecinde yardım istemeyi bazı değişkenlere göre inceleyen (Nelson-Le Gall, 2006; Newman, 1990; Nye, 2008; Ryan, Hicks ve Midgley, 1997; Ryan, Pintrich ve Midgley, 2001; Ryan ve Pintrich, 1997; Turner vd., 2002; Vaessen, Prins ve Jeuring, 2013) birçok araştırma olduğu görülmüştür.

Literatür incelendiğinde tükenmişlik ile alakalı araştırmaların daha çok lise düzeyi öğrencilerine yönelik olduğu, son zamanlarda üniversite öğrencilerine yönelik çalışmalarda artış olduğu görülürken ortaokul öğrencilerine yönelik çalışmaların sayısının kısıtlı olması dikkat çekmiştir. Öğrenme sürecinde yardım isteme ile ilgili ülkemizde yapılan araştırmalar incelendiğinde ise bu konu ile ilgili çok sınırlı çalışmalar olduğu görülmüştür. Araştırma konumuzun değişkenleri olan okul tükenmişliği, öğrenme sürecinde yardım isteme ve akademik başarı bireyin hem kişisel özelliklerinden etkilenen hem de birbiri ile ilişkisi olan değişkenler olarak düşünülmektedir.

$\mathrm{Bu}$ araştırmanın temel amacı, 6. 7. ve 8. sınıf öğrencilerinin okul tükenmişliği ve öğrenme sürecinde yardım isteme ile akademik başarı düzeyleri arasındaki ilişkileri belirlemektir. Bu temel amaca bağlı olarak aşağıdaki sorulara yanıt aranmıştır. Ortaokul 6. 7. ve 8. Sınıf öğrencilerinin; midir?

1) Okul tükenmişlik düzeyleri ile genel akademik başarıları arasında anlamlı bir ilişki var

2) Öğrenme sürecinde yardım isteme düzeyleri ile genel akademik başarıları arasında anlamlı bir ilişki var mıdır?

3) Okul tükenmişlik düzeyleri ile öğrenme sürecinde yardım isteme düzeyleri arasında anlamlı bir ilişki var mıdır?

\section{Yöntem}

\subsection{Araştırma Deseni}

$\mathrm{Bu}$ araştırmada tarama modellerinden ilişkisel tarama modeli kullanılmıştır. Tarama modelleri, bir grubun çeşitli özelliklerini tespit etmek için verilerin toplanmasını hedefleyen araştırmalardır (Büyüköztürk, Çakmak, Akgün, Karadeniz ve Demirel, 2014). İlişkisel tarama modeli ise iki ve daha çok değişken arasındaki değişimin varlığını veya derecesini belirlemeyi amaçlayan araştırma modelleridir (Karasar, 2015). Bu modelin araştırmada tercih edilmesinin sebebi öğrencilerin okul tükenmişliği, öğrenme sürecinde yardım isteme düzeyleri ve akademik başarıları arasındaki ilişkiyi belirlemeye olanak vermesidir. 


\subsection{Evren ve Örneklem}

Araştırmanın evrenini, 2015-2016 eğitim öğretim yılında Siirt merkez ilçesinde bulunan devlet ortaokullarında okuyan toplam 13.457 öğrenci oluşturmaktadır. Araştırmanın örneklemini ise seçkisiz örnekleme yöntemlerinden basit seçkisiz örnekleme yoluyla çalışmaya dâhil edilmiş 12 farklı ortaokuldan tabakalı örnekleme yöntemi ile araştırmaya dahil edilen 340 altıncı sınıf, 334 yedinci sınıf ve 316 sekizinci sınıf öğrencisi olmak üzere toplam 990 (dokuz yüz doksan) öğrenci oluşturmaktadır. Örneklem grubuna dâhil edilen öğrencilere ilişkin bilgiler Tablo 1'de verilmiştir.

Tablo 1. Araştırmaya katılan öğrencilere ait demografik bilgiler

\begin{tabular}{ccc}
\hline & (f) & $(\%)$ \\
\hline Erkek & 459 & 46,3 \\
K1z & 531 & 53,6 \\
\hline 6. sinif & 340 & 34,3 \\
7. sinif & 334 & 33,7 \\
8. sinif & 316 & 31,9 \\
\hline Toplam & 990 & 100 \\
\hline
\end{tabular}

Tablo 1 incelendiğinde örneklem grubunu oluşturan öğrencilerin \%46,3'ü erkeklerden, \%53,6'sı ise kızlardan oluşmaktadır. Araştırmaya katılan öğrencilerin \%34,3'ü 6. sınıf, \%33,7'si 7. sınıf ve \%31,9'u 8. sınıf öğrencilerinden oluşmaktadır. Buna göre örneklem grubunun cinsiyet ve sinıf açısında dengeli olduğu söylenebilir.

\subsection{Veri Toplama Araçları}

\subsubsection{Okul Tükenmişliği Ölçeği}

Aypay (2011) tarafından geliştirilen "Okul Tükenmişliği Ölçeğì"nin ölçüt geçerliğini incelemek için Akademik Beklentilere İlişkin Stres Envanteri-Aile/Öğretmen Beklentileri ve Akademik Beklentilere İlişkin Stres Envanteri- Kendine İlişkin Beklentiler ölçeklerinden alına puanlar karşılaştırılmıştır. “Okul Tükenmişliği Ölçeği”nin güvenirliği Cronbach Alpha katsayısı ve iki-yarı test güvenirliği yöntemleriyle ölçülmüş̧ür. Ölçeğin "Okul Etkinliklerinden Kaynaklı Tükenmişlik", "Aileden Kaynaklı Tükenmişlik", "Okulda Yetersizlik”, "Okula İlgi Kaybı" alt faktörleri için hesaplanan Cronbach Alpha iç tutarlılık katsayıları sırasıyla; .92, .83, .76 ve .81' dir. Alt faktörler için hesaplanan iki-yarı test güvenirliğinin de sırasıyla; $.81, .72, .65$ ve .65 olduğu belirlenmiştir (Aypay, 2011). Bu araştırma için yapılan güvenirlik analizinde ise tükenmişlik ölçeği için Cronbach Alpha iç tutarlılık katsayısı ölçek alt boyutları için sırasıyla .86, .74, .70 ve .74 olarak hesaplanmıştır.

\subsection{2. Öğrenme Sürecinde Yardım İsteme Ölçeği}

Araştırmada 6., 7. ve 8. sınıf öğrencilerinin öğrenme sürecinde yardım isteme durumlarını belirlemek amacıyla Koç (2013) tarafından geliştirilmiş olan Öğrenme Sürecinde Yardım İsteme Ölçeği kullanılmıştır.

Ölçeğin bütünü için Cronbach Alpha katsayısı .87, Yardım İstemeden Kaçınma için .87, Etkili Yardım İsteme için .79, Yüzeysel Yardım İsteme için .70 bulunmuştur. Ölçeğin test-tekrar test korelasyonları alt boyutlar için sırasıyla için $.81, .77, .77$, ölçeğin tamamı için .81 olarak hesaplanmıştır. Ölçeğin tümü ve alt boyutları için test-tekrar test güvenirlik katsayıları ile Cronbach Alpha iç tutarlılık katsayılarının kabul edilebilir derecede olduğu görülmektedir (Koç, 2013). Bu araştırma için yapılan güvenirlik analizinde öğrenme sürecinde yardım isteme ölçek geneli için Cronbach Alpha iç tutarlılık katsayısı 0.83 ve ölçek alt boyutları olan için sırasıyla $0.80,0.77$ ve 0.66 olarak hesaplanmıştır. Büyüköztürk'e (2014: 183) göre analizlerde hesaplanan güvenirlik katsayısının .70 ve daha yüksek olması test puanlarının güvenilirliği için yeterli bir puan olarak görülmektedir. Özdamar'a (1999) göre ise 0.60 - 0.80 aralığ 1 oldukça güvenilir, 0,80 $-1,00$ aralığı ise yüksek derecede güvenilir bir ölçektir. 


\subsubsection{Genel Akademik Bașarı}

Öğrencilerin genel akademik başarılarını tespit etmek için; örnekleme dâhil edilen ortaokulların okul idareleri ile görüşülmüş, alınan izinler çerçevesinde 2015-2016 eğitim-öğretim yılı 1. dönem karne not ortalamaları e okul sistemi üzerinden öğrenci numaraları ile birlikte temin edilmiştir.

\subsection{Verilerin Analizi}

Araştırmaya kaynaklık eden veriler öncelikli olarak okul, cinsiyet ve sınıf değişkenlerine göre tasnif edilmiş ve her öğrenciye ait okul tükenmişliği, öğrenme sürecinde yardım isteme ve genel akademik başarı puanları ile bir araya getirilmiştir. Öğrencilere uygulanan ölçeklerden eksik doldurulanlar araştırmaya dâhil edilmemiştir. Yapılan tasnif sonucunda 1132 öğrenciden 990 öğrenciye ait verilerin uygun olduğu tespit edilmiştir. Verilerin çözümlenmesi aşamasında SPSS 21 programı kullanılmıştır. Verilerin analizinde Pearson korelasyon katsayısı analizleri uygulanmıştır. Verilerin normal dağılım gösterip göstermediğini belirmek için ölçeklerin alt boyutları için çarpıklık ve basıklık katsayıları incelenmiş olup +1 ve -1 arasında değerler olduğu görülmüştür. Morgan ve ark. (2004) çarpıklık ve basıklık değerlerinin +1 ve -1 arasında olmasının normallik için genel geçer bir kural olarak kabul etmeyi önermektedirler (Akt., Can, 2014, 85).

\section{Bulgular}

Öğrencilerin okul tükenmişliği ve alt boyutları ile akademik başarıları arasında ilişki olup olmadığını belirlemek amacıyla Pearson korelasyon testi yapılmıştır. Elde edilen bulgular Tablo 2'de verilmiştir.

Tablo 2. Okul tükenmişliği ile akademik başarıları arasındaki ilişkiye yönelik Pearson momentler çarpımı korelasyon sonuçları

\begin{tabular}{lcccccc}
\hline & Okul Tükenmişliği & $\begin{array}{c}\text { Okul } \\
\text { Etkinliklerinden } \\
\text { Kaynaklı } \\
\text { Tükenmişlik }\end{array}$ & $\begin{array}{c}\text { Aileden } \\
\text { Kaynaklı } \\
\text { Tükenme }\end{array}$ & $\begin{array}{c}\text { Okulda } \\
\text { Yetersizlik }\end{array}$ & $\begin{array}{c}\text { Okula } \\
\text { Ilgi } \\
\text { Kayb1 }\end{array}$ \\
\hline \multirow{3}{*}{ Akademik Başarı } & $\mathrm{r}$ & $-0,231^{*}$ & $-0,221^{*}$ & $-0,114^{*}$ & $-0,148^{*}$ & $-0,209^{*}$ \\
& $\mathrm{p}$ & $\mathbf{0 , 0 0 0}$ & $\mathbf{0 , 0 0 0}$ & $\mathbf{0 , 0 0 0}$ & $\mathbf{0 , 0 0 0}$ & $\mathbf{0 , 0 0 0}$ \\
& $\mathrm{N}$ & 990 & 990 & 990 & 990 & 990 \\
\hline *p
\end{tabular}

$* p<0,05$

Tablo 2 incelendiğinde öğrencilerin okul tükenmişliği ve tüm alt boyutları ile akademik başarıları arasında, negatif yönde ve anlamlı düzeyde bir ilişki olduğunu göstermektedir $(p<0,05)$. Pearson momentler çarpımı kolerasyon katsayısının mutlak değer olarak 0,70-1,00 arasında olmas1 yüksek; $0,70-0,30$ arasında olması orta; 0,30-0,00 olmas1 ise düşük düzeyde bir ilişki olarak tanımlanabilir (Büyüköztürk, 2014). Buradan hareketle genel okul tükenmişliği ve alt boyutları olan okul etkinliklerinden kaynaklı tükenmişlik ve okula ilgi kaybı ile akademik başarı arasında zayıf düzeyde ve negatif yönde anlamlı bir ilişki $(r=-0,23 ; r=-0,21 ; r=-0,21 ; p<0,05)$ olduğu söylenebilir. Aileden kaynaklı tükenmişlik ve okulda yetersizlik alt boyutları ile akademik başarı arasında ise negatif yönde ve çok zayıf düzeyde anlamlı bir ilişki $(r=-0,11 ; r=-0,15$; $\mathrm{p}<0,05)$ olduğu söylenebilir.

Öğrencilerin öğrenme sürecinde yardım istemeleri ve alt boyutları ile akademik başarıları arasında ilişki olup olmadığını belirlemek amacıyla Pearson korelasyon testi yapılmıştır. Elde edilen bulgular Tablo 3'te verilmiştir. 
Tablo 3. Öğrenme sürecinde yardım isteme ile akademik başarıları arasındaki ilişkiye yönelik Pearson momentler çarpımı korelasyon sonuçları

\begin{tabular}{cccccc}
\hline & & $\begin{array}{c}\text { Öğrenme } \\
\text { Sürecinde Yardım } \\
\text { İsteme }\end{array}$ & $\begin{array}{c}\text { Yardım } \\
\text { İstemeden } \\
\text { Kaçınma }\end{array}$ & $\begin{array}{c}\text { Etkili Yardım } \\
\text { İsteme }\end{array}$ & $\begin{array}{c}\text { Yüzeysel } \\
\text { Yardım İsteme }\end{array}$ \\
\hline \multirow{2}{*}{ Akademik Başarı } & $\mathrm{r}$ & $0,456^{*}$ & $-0,307^{*}$ & $0,312^{*}$ & $-0,423^{*}$ \\
& $\mathrm{p}$ & $\mathbf{0 , 0 0 0}$ & $\mathbf{0 , 0 0 0}$ & $\mathbf{0 , 0 0 0}$ & $\mathbf{0 , 0 0 0}$ \\
& $\mathrm{N}$ & 990 & 990 & 990 & 990 \\
\hline
\end{tabular}

$*_{p}<0,05$

Tablo 3 incelendiğinde öğrenme sürecinde yardım isteme ve alt boyutu olan etkili yardım isteme ile akademik başarı arasında, pozitif yönde ve orta düzeyde anlamlı bir ilişki $(r=0,456 ; r$ $=0,312 ; \mathrm{p}<0,05) ;$ yardım istemeden kaçınma ve yüzeysel yardım isteme alt boyutları ile akademik başarı arasında, negatif yönde ve orta düzeyde anlamlı bir ilişki $(r=-0,307 ; r=-0,423 ; p<0,05)$ olduğu görülmektedir. Buna göre akademik başarı düzeyi arttıkça öğrenme sürecinde yardım isteme düzeyi ile etkili yardım isteme düzeyi artmakta, yardım istemeden kaçınma düzeyi ile yüzeysel yardım isteme düzeyi azalmaktadır.

Öğrencilerin okul tükenmişlikleri ile öğrenme sürecinde yardım isteme durumları arasında ilişki olup olmadığını belirlemek amacıyla Pearson korelasyon testi yapılmıştır. Elde edilen bulgular Tablo 4'te verilmiştir.

Tablo 4. Okul tükenmişliği ile öğrenme sürecinde yardım isteme arasındaki ilişkiye yönelik Pearson momentler çarpımı korelasyon sonuçları

\begin{tabular}{lccccc}
\hline & & $\begin{array}{c}\text { Öğrenme } \\
\text { Sürecinde } \\
\text { Yardım İsteme }\end{array}$ & $\begin{array}{c}\text { (1) Yardım } \\
\text { İstemeden } \\
\text { Kaçınma }\end{array}$ & $\begin{array}{c}\text { (2) Etkili } \\
\text { Yardım } \\
\text { İsteme }\end{array}$ & $\begin{array}{c}\text { (3) Yüzeysel } \\
\text { Yardım } \\
\text { İsteme }\end{array}$ \\
\hline \multirow{3}{*}{ Okul Tükenmişliği } & $\mathrm{r}$ & $-0,430^{*}$ & $0,367^{*}$ & $-0,263^{*}$ & $0,326^{*}$ \\
& $\mathrm{p}$ & $\mathbf{0 , 0 0 0}$ & $\mathbf{0 , 0 0 0}$ & $\mathbf{0 , 0 0 0}$ & $\mathbf{0 , 0 0 0}$ \\
& $\mathrm{N}$ & 990 & 990 & 990 & 990 \\
\hline \multirow{2}{*}{ (1) Okul Etkinliklerinden } & $\mathrm{r}$ & $-0,383^{*}$ & $0,307^{*}$ & $-0,253^{*}$ & $0,295^{*}$ \\
Kaynaklı Tükenmişlik & $\mathrm{p}$ & $\mathbf{0 , 0 0 0}$ & $\mathbf{0 , 0 0 0}$ & $\mathbf{0 , 0 0 0}$ & $\mathbf{0 , 0 0 0}$ \\
& $\mathrm{N}$ & 990 & 990 & 990 & 990 \\
\hline \multirow{3}{*}{ (2) Aileden Kaynaklı Tükenmen } & $\mathrm{r}$ & $-0,287^{*}$ & $0,275^{*}$ & $-0,145^{*}$ & $0,214^{*}$ \\
& $\mathrm{p}$ & $\mathbf{0 , 0 0 0}$ & $\mathbf{0 , 0 0 0}$ & $\mathbf{0 , 0 0 0}$ & $\mathbf{0 , 0 0 0}$ \\
& $\mathrm{N}$ & 990 & 990 & 990 & 990 \\
\hline \multirow{3}{*}{ (3) Okulda Yetersizlik } & $\mathrm{r}$ & $-0,314^{*}$ & $0,343^{*}$ & $-0,138^{*}$ & $0,201^{*}$ \\
& $\mathrm{p}$ & $\mathbf{0 , 0 0 0}$ & $\mathbf{0 , 0 0 0}$ & $\mathbf{0 , 0 0 0}$ & $\mathbf{0 , 0 0 0}$ \\
& $\mathrm{N}$ & 990 & 990 & 990 & 990 \\
\hline \multirow{3}{*}{ (4) Okula İlgi Kaybi } & $\mathrm{r}$ & $-0,325^{*}$ & $0,219^{*}$ & $-0,242^{*}$ & $0,275^{*}$ \\
& $\mathrm{p}$ & $\mathbf{0 , 0 0 0}$ & $\mathbf{0 , 0 0 0}$ & $\mathbf{0 , 0 0 0}$ & $\mathbf{0 , 0 0 0}$ \\
& $\mathrm{N}$ & 990 & 990 & 990 & 990 \\
\hline
\end{tabular}

$*_{p}<0,05$

Okul tükenmişliği ile öğrenme sürecinde yardım isteme arasında orta düzeyde ve negatif yönde anlamlı bir ilişki $(r=-0,430 ; p<0,05)$ bulunmuştur. Okul tükenmişliği ile Etkili yardım isteme arasında zayıf düzeyde ve negatif yönde anlamlı bir ilişki $(r=-0,263 ; p<0,05)$ tespit edilmiştir. Okul tükenmişliği ile yardım istemeden kaçınma ve yüzeysel yardım isteme alt boyutları arasında ise orta düzeyde ve pozitif yönde anlamlı bir ilişki $(r=0,367 ; r=0,326 ; p<0,05)$ olduğu tespit edilmiştir. 
Okul etkinliklerinden kaynaklı tükenmişlik alt boyutu ile öğrenme sürecinde yardım isteme alt boyutu arasında orta düzeyde ve negatif yönde anlamlı bir ilişki $(r=-0,383 ; p<0,05)$ olduğu görülmektedir. Okul etkinliklerinden kaynaklı tükenmişlik alt boyutu ile etkili yardım isteme alt boyutu arasında ise zayıf düzeyde ve negatif yönde anlamlı bir ilişki $(r=-0,253$; $\mathrm{p}<0,05)$ tespit edilmiştir. Okul etkinliklerinden kaynaklı tükenmişlik alt boyutu arasında orta düzeyde ve pozitif yönde anlamlı bir ilişki $(\mathrm{r}=0,307 ; \mathrm{p}<0,05)$ tespit edilmiştir. Okul etkinliklerinden kaynaklı tükenmişlik alt boyutu ile yüzeysel yardım isteme alt boyutu arasında ise zayıf düzeyde ve pozitif yönde anlamlı bir ilişki $(r=0,295 ; \mathrm{p}<0,05)$ tespit edilmiştir.

Aileden kaynaklı tükenme alt boyutu ile öğrenme sürecinde yardım isteme ve etkili yardım isteme alt boyutları arasında zayıf düzeyde ve negatif yönde bir ilişki $(r=-0,287 ; r=-$ 0,$145 ; \mathrm{p}<0,05$ ) olduğu belirlenmiştir. Aileden kaynaklı tükenme alt boyutu ile yardım istemeden kaçınma ve yüzeysel yardım isteme alt boyutları arasında ise zayıf düzeyde ve pozitif yönde bir ilişki $(r=0,275 ; r=0,214 ; p<0,05)$ olduğu tespit edilmiştir.

Okulda yetersizlik alt boyutu ile ögrenme sürecinde yardım isteme alt boyutu arasında orta düzeyde ve negatif yönde bir ilişki $(r=-0,314 ; p<0,05)$ olduğu tespit edilmiştir. Okulda yetersizlik alt boyutu ile etkili yardım isteme alt boyutu arasında ise çok zayıf düzeyde ve negatif yönde anlamlı bir ilişki $(\mathrm{r}=-0,138 ; \mathrm{p}<0,05)$ tespit edilmiştir. Okulda yetersizlik alt boyutu ile yardım istemeden kaçınma alt boyutu arasındaki zayıf düzeyde ve pozitif yönde anlamlı bir ilişki $(\mathrm{r}=0,343 ; \mathrm{p}<0,05)$ tespit edilmiştir. Okulda yetersizlik alt boyutu ile yüzeysel yardım isteme alt boyutu arasında ise zayıf düzeyde ve pozitif yönde anlamlı bir ilişki $(r=0,201 ; p<0,05)$ olduğu tespit edilmiştir.

Okula ilgi kaybı alt boyutu ile öğrenme sürecinde yardım isteme arasında orta düzeyde ve negatif yönde anlamlı bir ilişki $(r=-0,325 ; \mathrm{p}<0,05)$ tespit edilmiştir. Okula ilgi kaybı alt boyutu ile yardım istemeden kaçınma ve yüzeysel yardım isteme alt boyutları arasında zayıf düzeyde ve pozitif yönde anlamlı $\operatorname{bir}(r=0,219 ; \mathrm{r}=0,275 ; \mathrm{p}<0,05)$ tespit edilmiştir. Okula ilgi kaybı alt boyutu ile etkili yardım isteme alt boyutu arasında ise zayıf düzeyde ve negatif yönde anlamlı bir ilişki $(\mathrm{r}=-0,242 ; \mathrm{p}<0,05)$ tespit edilmiştir.

\section{Tartışma, Sonuç ve Öneriler}

Araştırmada okul tükenmişliği ve alt boyutları olan okul etkinliklerinden kaynaklı tükenmişlik, aileden kaynaklı tükenmişlik, okulda yetersizlik tükenmişliği ve okula ilgi kaybı ile akademik başarı arasında anlamlı bir ilişki olduğu sonucuna ulaşılmıştır. Araştırmanın verilerinden elde edilen bulgulara göre okul tükenmişlik durumu düşük düzeyde olan öğrencilerin akademik başarılarının arttı̆̆ını söylemek mümkündür. Okul tükenmişliği ile akademik başarı arasında ters bir ilişki bulgusunun olması beklenen bir durumdur. Ancak ilişkinin düşük düzeyde olması beklenen bir durum değildir. Öğrencilerin okul ile ilgili olumsuz duygularında artışlar meydana gelmesi, onların okulda geçirdikleri zamanları verimsiz ve etkisiz kullanmalarına sebebiyet vermektedir (Aypay ve Eryılmaz, 2011a). Özdemir (2015) yapmış olduğu çalışmada akademik motivasyonun okul tükenmişliğinin anlamlı bir yordayıcısı olduğunu, ödeve daha az vakit ayıran, okula bağlı olan ve akademik motivasyonu yüksek olan öğrencilerin okul tükenmişliğinin düşük olduğunu ifade etmiştir. Bazı araştırmalarda elde edilen bulgulardan farklı sonuçlar elde edilmiştir. Demir (2015) akademik başarısı daha yüksek düzeyde olan öğrencilerin tükenmişlik durumunu daha yüksek düzeyde olduğu sonucuna ulaşmıştır. Aynı şekilde Çavuşoğlu (2009), Çapulcuoğlu (2012) yapmış oldukları çalışmalarda araştırmamız sonuçları ile çelişen sonuçlar elde etmişlerdir. Bazı araştırma sonuçları ile bu çalışmanın sonuçları ise paralellik göstermektedir. Örneğin, yapılan diğer çalışmalara (Özgen, 2016; Seçer ve Gençdoğan, 2012; Kutsal ve Bilge, 2012) tükenmişlik düzeyi azaldıkça akademik başarı düzeyinin arttı̆̆ sonucuna ulaşmışlardır. Öğrencilerin verimli ve etkili geçirilen derslerinin olması, bu derslerin anlaşılacağı sonucunu doğurabileceğinden öğrencinin akademik başarısında yükselmeler meydana gelebileceği söylenebilir. 
Araştırmada akademik başarı ile öğrenme sürecinde yardım isteme ve etkili yardım isteme alt boyutunda pozitif yönde, yardım istemeden kaçınma ve yüzeysel yardım isteme alt boyutlarında ise negatif yönde anlamlı bir ilişki olduğu sonucuna ulaşılmıştır. Araştırmanın verilerinden elde edilen bulgulara göre öğrenme sürecinde yardım isteme durumu yüksek düzeyde olan öğrencilerin akademik başarılarını arttığını söylemek mümkündür. Ancak akademik başarıları düşük olan öğrencilerin öğrenme sürecinde daha az yardım istedikleri söylenebilir. Öğrenme sürecinde sunulan bir konuyu anlamayan öğrenci; öğretmen, aile, arkadaş veya akranlarından yardım isterse anlamadığı konuyu anlama olasılığı artabileceğinden akademik başarısında da artışlar meydana gelebilir. Nitekim Atik, Özer ve Karadağ (2018) yaptıkları çalışmada öğretmenlere güvenin okul tükenmişliğindeki varyansın yaklaşık \%18'ini, öğretmenlere güven ve okul tükenmişliği değişkenleri birlikte akademik başarıdaki varyansın yaklaşık \%8'ini açıkladığı belirlenmiştir. Öğrenme sürecinde yardım isteme ile akademik başarı arasında doğru orantılı bir ilişki olması beklenen bir durumdur. Güvenç ve Koç ortaokul öğrencilerinin derse etkin katılımları ile yardım isteme eğilimleri arasında anlamlı ilişki bulunduğunu, öğrencilerde hoşnutsuzluk arttıkça yardım istemekten kaçınma ve yüzeysel yardım istemenin arttığını tespit etmiştir. Ryan, Hicks ve Midgley (1997)'e göre başarı seviyesi düşük olan öğrencilerde yardım isteme konusunda olumsuz endişeler meydana gelmektedir. Ryan ve Pintrich'in (1997), araştırmaları neticesinde fayda, yardım isteme davranışına uyum göstermiştir. Nye (2008) çalışmasında öğrencilerin bir etkinlik konusunda bilgilerini geliştirmek ya da arttırmak için veya iyi bir not almak için yardım istediklerini belirlemiştir. Söz konusu araştırmaların sonuçları, bu çalışmanın ortaya koyduğu bulguları destekler mahiyettedir.

Araştırmada öğrencilerin okul tükenmişlik ve alt boyutları olan okul etkinliklerinden kaynaklı tükenmişlikleri, aileden kaynaklı tükenmeleri, okuldaki yetersizlikleri ve okula ilgi kaybı tükenmeleri ile ögrrenme sürecinde yardım isteme ve alt boyutları olan yardım istemeden kaçınma, etkili yardım isteme ve yüzeysel yardım isteme durumları arasında anlamlı bir ilişkinin olduğu sonucuna ulaşılmıştır. Öğrenme sürecinde yardım isteme ve etkili yardım isteme boyutlarının okul tükenmişliği ve tüm alt boyutlarını negatif yönde etkilediği tespit edilmiştir. Ayrıca yardım istemeden kaçınma ve yüzeysel yardım isteme boyutlarının ise okul tükenmişliği ve tüm alt boyutlarını pozitif yönde etkilediği tespit edilmiştir. Okul tükenmişliğinin öğrenme sürecinde yardım istemeyi orta düzeyde, aileden kaynaklı tükenme ve okulda yetersizlik boyutlarının etkili yardım isteme durumunu çok zayıf düzeyde ve diğer tüm boyutların birbirlerini zayıf düzeyde etkilediği tespit edilmiştir. Araştırmanın verilerinden elde edilen bulgulara göre okul tükenmişlik düzeyi yüksek olan öğrencinin öğrenme sürecinde yardım isteme düzeyinde azalmalar meydana geldiğini söylemek mümkündür. Başka bir ifadeyle okula gelmek istemeyen, okuldan sıkılan, okulu sevmeyen, ailenin yapmış olduğu baskı neticesinde bekleneni veremeyen ve okulda hayal kırıklığı yaşayan öğrencilerin okulu seven, okulda güzel vakit geçiren ve okulda sıkılmayan öğrencilere göre daha az yardım istedikleri söylenebilir. Öğrenme süreci içerisinde öğretmen, akran veya ailesinden yardım isteyen bir öğrencinin okula olan ilgisinde artış olduğu söylenebilir.

Araştırma sonuçlarına dayalı olarak öğretmen-öğrenci, öğrenci-öğrenci ilişkilerini ve yardım alma becerilerini geliştirecek iş birliğine dayalı öğrenme ortamları oluşturulabilir. Öğretmenler tarafından öğrencilere yardım isteme alışkanlığı kazandırabilmek amacıyla öğrencileri yardım istemeye yönlendirecek çalışmalar yaptırılabilir. Okul tükenmişliğini artıran sebepler araştırılarak rehberlik çalışmaları yapılabilir. Bu araştırma devlet okullarında okuyan öğrenciler ile gerçekleştirilmiştir. Benzer araştırmalar devlet okulları ve özel okullarda okuyan farklı kademelerdeki öğrenci grupları üzerinde yapılabilir. 


\section{Kaynakça}

Akbaşl1, S., Arastaman, G., Gün, F., \& Turabik, T. (2019). School engagement as a predictor of burnout in university students. Pamukkale Üniversitesi Ĕ̆itim Fakültesi Dergisi, 45(45), 293 309.

Altuntaş, S., \& Sezer, Ö. (2017). Ortaokul öğrencilerinin okula bağlanmalarının incelenmesi. Inonu University Journal of the Faculty of Education (INUJFE), 18(1).

Atik, S., Özer, N., \& Karadağ, N. (2018). Öğrencilerin öğretmenlerine güven düzeyleri, okul tükenmişlikleri ile akademik başarılarının yapısal eşitlik modellemesiyle incelenmesi. Adryaman University Journal of Educational Sciences, 8(2), 259-283,

Avara, K. (2015). Ortaöğretim ögrencelerinde akademik güdülenmenin yordayıcısı olarak akademik öz-yeterlik, kariyer kararı yetkinlik beklentisi ve okul tükenmişliği (Yayımlanmamış yüksek lisans tezi). Mevlâna Üniversitesi, Konya.

Aypay, A. (2011). İlköğretim II. Kademe öğrencileri için okul tükenmişliği ölçeği: Geçerlik ve güvenirlik çalışması. Kuram ve Uygulamada Eğitim Bilimleri. 11(2), 511-527.

Aypay, A. \& Eryılmaz, A. (2011). Lise öğrencilerinin öznel iyi oluşları ve okul tükenmişliği arasındaki ilişkiler. International Online Journal of Educational Sciences, 3(1), 181-199.

Aypay, A. ve Eryılmaz, A. (2011a). Lise öğrencilerinin derse katılmaya motive olmaları ile okul tükenmişliği arasındaki ilişkinin incelenmesi. Mehmet Akif Ersoy Üniversitesi Ĕ̈itim Fakültesi Dergisi, 21, 26 - 44.

Aypay, A. \& Sever, M. (2015). School as if a workplace: exploring burnout among high school students. Eğitimde Kuram ve Uygulama, 11(2), 460-472.

Baş, G. (2012). İlköğretim öğrencilerinde tükenmişlik: farklı değişkenler açısından bir değerlendirme. Journal of European Education. 2, 2146-2674.

Büyüköztürk, Ş. (2014). Sosyal bilimler için veri analizi el kitabı. Ankara: Pegem Akademi Yayıncilik.

Büyüköztürk, Ş., Kılıç Çakmak, E., Akgün, Ö. E., Karadeniz, Ş. \& Demirel, F. (2014). Bilimsel araştırma yöntemleri (16. Baskı). Ankara: Pegem Akademi Yayıncılık.

Can, A. (2014). SPSS ile bilimsel araştırma sürecinde nicel veri analizi. Ankara: Pegem Akademi Yayıncilik.

Çakır, M. A. (2015). Lise öğrencilerinin tükenmişlik düzeylerinin incelenmesi (Yeşilova ilçesi örneği). Mehmet Akif Ersoy Üniversitesi Eğitim Fakültesi Dergisi, 1(34), 152-168.

Çakmak, A., \& Şahin, H. (2017). Ortaokula devam eden öğrencilerin algıladıkları sosyal desteğin okul tükenmişliğine etkisinin incelenmesi. Electronic Journal of Social Sciences, 16(61), 569582.

Çam, Z., Deniz K. Z. \& Kurnaz A. (2014). Okul tükenmişliği: algılanan sosyal destek, mükemmeliyetçilik ve stres değişkenlerine dayalı bir yapısal eşitlik modeli sınaması. Eğitim ve Bilim. 39(173), 312-325.

Çapri, B., Gündüz, B. \& Gökçakan, Z. (2011). Maslach tükenmişlik envanteri-öğrenci formu (MTE-ÖF)'nun türkçe'ye uyarlaması: geçerlik ve güvenirlik çalışması, Çukurova Üniversitesi Eğitim Fakültesi Dergisi. 40(1),134-147.

Çapulcuoğlu, U. (2012). Öğrenci tükenmişliğini yordamada stresle başa çıkma, sınav kaygısı, akademik yetkinlik ve anne-baba tutumları değişkenlerinin incelenmesi (Yayımlanmamış yüksek lisans tezi). Mersin Üniversitesi, Mersin. 
Çavuşoğlu, İ. (2009). Sinıf ögretmenliği son sınıf öğretmen adaylarının tükenmişlik düzeylerinin incelenmesi. (Yayımlanmamış doktora tezi). Çukurova Üniversitesi, Adana.

Demir, M. (2015). Okul tükenmişliğinin yordanmasında sınav kaygısı ve akademik başarının etkisi (Yayımlanmamış yüksek lisans tezi). Atatürk Üniversitesi, Erzurum.

Eker, G. (2007). Endüstri meslek lisesi öğrencilerinin tükenmişlik düzeyleri (Yayımlanmamış yüksek lisans tezi). Marmara Üniversitesi, Ankara.

Gündüz, B., Çapri, B. \& Gökçakan, Z. (2012). Üniversite öğrencilerinin tükenmişlik düzeylerinin incelenmesi. Dicle Üniversitesi Ziya Gökalp Eğitim Fakültesi, 38(19), 38-55.

Güvenç, H. \& Koç, C. (2016). Ortaokul öğrencilerinin etkin katılımı ve yardım isteme eğilimleri. Trakya Üniversitesi Sosyal Bilimler Dergisi, 18(2), 347-366.

Karasar, N. (2015). Bilimsel araştırma yöntemleri (28. Baskı). Ankara: Nobel Yayın Dağıtım.

Kiuru, N., Aunola, K., Nurmi, J. E., Leskinen, E., \& Salmela-Aro, K. (2008). Peer group influence and selection in adolescents' school burnout: a longitudinal study. Merrill-Palmer Quarterly (1982-), 23-55.

Koç, C. (2013). Öğrenme sürecinde yardım isteme ölçeği (ösyiö): geçerlik ve güvenirlik çalışması. İlkögretim Online, 12(3), 784-796.

Koç, C. (2014). Öğrenme sürecinde etkili yardım isteme: bir öz düzenleme stratejisi. Elektronik Sosyal Bilimler Dergisi, 13(50), 139-160.

Koç, C. (2015). İlköğretim öğrencilerinin problem çözme becerilerine yönelik algıları ve öğrenme sürecinde yardım istemeleri. K. Ü. Kastamonu Eğitim Dergisi, 23(2), 659-678.

Koçak, L., \& Secer, I. (2018). Investigation of the relationship between school burnout, depression and anxiety among high school students. Cukurova University Faculty of Education Journal, 47(2).

Körükcü, M., \& Uslu, S. (2018). Ortaokul öğrencilerinin öğrenme sürecinde yardım isteme düzeylerinin demografik değişkenler açısından incelenmesi. Electronic Turkish Studies, 13(19). 1235-1247.

Kutsal, D. (2009). Lise öğrencilerinin tükenmişliklerinin incelenmesi (Yayımlanmamış yüksek lisans tezi). Hacettepe Üniversitesi, Ankara.

Kutsal, D. \& Bilge, F. (2012). Lise öğrencilerinin tükenmişlik ve sosyal destek düzeyleri. Eğitim ve Bilim, 37(164), 284-297.

Küçüksüleymanoğlu, R. \& Onuray-Eğilmez, H. (2013). Müzik öğretmeni adaylarının tükenmişlik düzeyleri: Uludağ üniversitesi örneği. International Journal of Social Science, 6(3), 905-923.

Mccarthy, M. E., Pretty, G. M., \& Catano, V. (1990). Psychological sense of community and student burnout. Journal of College Student Development, 31, 211-216.

Nelson-Le Gall, S. (2006). Peer acceptance and black children's help-seeking in school. Negro Educational Review, 57(1/2), 5.

Nelson-Le Gall, S. \& Resnick, L. (1998). Help seeking, achievement motivation, and the social practice of intelligence in school. A. Karabenick (Eds), Strategic help seeking implications for learning and teaching. (ss: 39-60 ) Mahwah, New Jersey: Lawrence Erlbaum.

Newman, R. S. (1990). Children's help-seeking in the classroom: The role of motivational factors and attitudes. Journal of Educational Psychology, 82(1), 71-80.

Nye, S. B., (2008). Students' help seeking during physical education. Journal of Teaching in Physical Education, 27, 368-384. 
Ören, N. \& Türkoğlu, H. (2006). Öğretmen adaylarında tükenmişlik. Muğla Üniversitesi Sosyal Bilimler Enstitüsü Dergisi, 16, 30-42.

Özbakır, E. (2015). Ortaokul öğrencilerinin insani değerleri ile okul tükenmişliği arasındaki ilişki ve bir araştırma (Yayımlanmamış yüksek lisans tezi). Yeditepe Üniversitesi, İstanbul.

Özdamar, K. (1999). Paket programlar ile istatistiksel veri analizi. Eskişehir: Kaan Kitabevi.

Özdemir, Y. (2015). Ortaokul öğrencilerinde okul tükenmișliği: Ödev, okula bağlılık ve akademik motivasyonun rolü. Adnan Menderes Üniversitesi Ĕgitim Fakültesi Eğitim Bilimleri Dergisi, 6(1), 27-35.

Özdemir, Y., \& Özdemir, M. (2015). Eğitim stresi ve benlik saygısının ortaokul öğrencilerinin okul tükenmişliği üzerindeki doğrudan ve dolaylı etkileri. Adnan Menderes Üniversitesi Eğitim Fakültesi Ĕgitim Bilimleri Dergisi, 6(2), 1-10.

Özgen, H. (2016). Üniversite ögrencilerinde okul tükenmişliği ile psikolojik yardım ihtiyacı arasındaki ilişkinin incelenmesi (Yayımlanmamış yüksek lisans tezi). Atatürk Üniversitesi, Erzurum.

Öztan, S. (2014). Ortaokul 6.7.8. Sinı öğrencilerinin okul tükenmişliklerinin yaşam doyumları ve benlik kurgusu algıları açısından incelenmesi (Yayımlanmamış yüksek lisans tezi). İstanbul Arel Üniversitesi, İstanbul.

Ryan, A. M., Pintrich, P. R., \& Midgley, C. (2001). Avoiding seeking help in the classroom: Who and why?. Educational Psychology Review, 13, 2.

Ryan, A., Hicks, L., \& Midgley, C. (1997). Social goals, academic goals, and avoiding seeking help in the classroom. Journal of Early Adolescence, 17(2), 152-171.

Ryan, A., \& Pintrich, P. R. (1997). Should I ask for help? The role of motivation and attitudes in adolescents' help seeking in math class. Journal of Educational Psychology, 89(2), 329-341.

Saban, A. (2005). Öğrenme öğretme süreci yeni teori ve yaklaşımlar. Ankara: Nobel Yayın Dağıtım.

Saka, D. (2016). Ortaokul öğrencilerinin müzik dersi yüklemeleri ile okul tükenmişliklerinin incelenmesi (Yayımlanmamış yüksek lisans tezi). Akdeniz Üniversitesi, Antalya.

Salmelo-Aro, K., \& Upadyaya, K. (2014). Developmental trajectories of school burnout: evidence from two longitudinal studies. Learning and Individual Differences, 36, 60-68.

Seçer, İ. (2015). Okul tükenmiş̧liği ile akademik güdülenme arasındaki ilişkinin yapısal eşitlik modeli ile incelenmesi. Eğitim ve Öğretim Araştırmaları Dergisi, 4(1), 424-433.

Seçer, İ. (2015a). Üniversite öğrencilerinde okul tükenmişliği ile psikolojik uyumsuzluk arasındaki ilişkinin incelenmesi. Atatürk Üniversitesi Sosyal Bilimler Enstitüsü Dergisi, 19 (1), 81-99.

Seçer, İ. \& Gençdoğan, B. (2012). Ortaöğretim öğrencilerinde okul tükenmişliğinin çeşitli değişkenler açısından incelenmesi. Turkish Journal of Education, 1(2), 1-13.

Şahan, B., \& Duy, B. (2017). Okul tükenmişliği: okula bağlanma, sosyal destek ve öz yeterliliğin yordayıc1 rolü. Mersin Üniversitesi Eğitim Fakültesi Dergisi, 13(3), 1249-1270.

Tansel, B. (2015). Üniversite öğrencilerinin tükenmişlik düzeylerinin incelenmesi. Çukurova University. Faculty of Education Journal, 44(2), 241.

Turner, J., Midgley, C., Meyer, D., Gheen, M., Anderman, E., Kang, Y., \& Patrick, H. (2002). The classroom environment and students' reports of avoidance strategies in mathematics: amultimethod study. Journal of Educational Psychology, 94(1), 88-106. 
Vaessen, B., Prins, F. \& Jeuring, J. (2013). University students' achievement goals and helpseeking strategies in an intelligent tutoring system. Department Of Information And Computing Sciences Utrecht University, Utrecht, The Netherlands.

Yang, H. J. \& Farn, C. K. (2005). An investigation the factors affecting mis student burnout in technical-vocational college. Computers in Human Behavior, 21, 917-932.

\section{ETIKK ve BİLIMSEL İLKELER SORUMLULUK BEYANI}

$\mathrm{Bu}$ çalışmanın tüm hazırlanma süreçlerinde etik kurallara ve bilimsel atıf gösterme ilkelerine riayet edildiğini yazarlar beyan eder. Aksi bir durumun tespiti halinde Afyon Kocatepe Üniversitesi Sosyal Bilimler Dergisi'nin hiçbir sorumluluğu olmayıp, tüm sorumluluk makale yazarlarına aittir. 